\title{
Normal human primary CD4 + T lymphocytes synthesize and release functional osteoprotegerin in vitro
}

\author{
Arpita Chakravarti ${ }^{1,2}$, Andrée-Anne Marceau ${ }^{1}$, Louis Flamand ${ }^{1}$ and Patrice E Poubelle ${ }^{1,2}$
}

Osteoprotegerin (OPG) acts as a decoy receptor for receptor activator of nuclear factor- $\kappa$ B ligand (RANKL) and TNF-related apoptosis-inducing ligand (TRAIL). OPG regulates bone remodeling and the immune response. The primary objective was to decipher, among human peripheral blood mononuclear leukocytes (PBML) that produce OPG, the subset(s) responsible for this synthesis and its regulation. To this end, normal human PBML and CD4-, 8-, 19-, 14-enriched subpopulations were studied in vitro for OPG synthesis. PBML were subjected to adherence and immunomagnetic separation, and OPG expression was analyzed by PCR, northern and western blotting, and ELISA. The antiapoptotic effects of OPG were studied on TRAIL-stimulated RPMI 8226 myeloma cells. OPG was time-dependently produced by primary $\mathrm{CD} 4+\mathrm{T}$ lymphocytes exclusively. OPG secretion was upregulated by anti-CD3 antibody stimulation or incubation with interleukin (IL)-4, IL-1 $\beta$, TNF- $\alpha$, GM-CSF, and vitamin $\mathrm{D}_{3}$. In contrast, IL-10 inhibited the basal and IL-4-induced production of OPG by T cells. Conditioned media from activated T lymphocytes decreased TRAIL-induced apoptosis of RPMI 8226 cells. This effect was reversed by addition of RANKL to the T-cell conditioned media. As human immunodeficiency virus- 1 (HIV-1) targets CD4 + T cells, we evaluated the effects of recombinant HIV-1 gp120 proteins on OPG synthesis. The gp120 from three different HIV-1 strains significantly reduced the basal output of OPG from T cells. Furthermore, all four protease inhibitors (PIs) used in highly active antiretroviral therapy decreased OPG synthesis by human blood T cells, nelfinavir being the most efficient PI. The simultaneous presence of an HIV-1 gp120 and a PI abrogated the basal output of OPG. In conclusion, these results highlight a new role for T lymphocytes involved in pathologies. Activated CD4 + T cells could, through OPG release, have a paracrine effect on adjacent cells and contribute to reduce the local process of bone remodeling and cellular apoptosis.

Laboratory Investigation (2008) 88, 171-184; doi:10.1038/labinvest.3700701; published online 26 November 2007

KEYWORDS: human T cells; osteoprotegerin; cytokines; TRAIL; apoptosis; myeloma cells; HIV-1 gp120

Osteoprotegerin (OPG) is a soluble glycoprotein of the tumor necrosis factor receptor superfamily. OPG functions as a decoy receptor by blocking the interaction between the ligands receptor activator of nuclear factor $\kappa \mathrm{B}$ ligand (RANKL) and TNF-related apoptosis-inducing ligand (TRAIL)/APO2L and their cognate receptors RANK and TRAIL-R1/TRAIL-R2, respectively. ${ }^{1,2}$ The RANK/RANKL system is necessary for osteoclast development and function. ${ }^{3}$ OPG regulates this system and protects bone, as demonstrated by the severe osteoporosis that present $\mathrm{OPG}^{-1-}$ mice. ${ }^{4}$ Indeed, the administration of OPG mitigates bone loss in animal models of osteoporosis and arthritis. ${ }^{4,5}$ OPG treatment of a T-cell-dependent arthritis in rats prevents bone and cartilage destruction by blocking the effects of RANKL produced by activated T lymphocytes. ${ }^{6}$ The RANK/ RANKL system is also implicated in dendritic cell-T lymphocyte interactions. ${ }^{7}$ Thus, dendritic cell survival, T lymphocyte activation and B lymphocyte development, maturation, and function are regulated by OPG. ${ }^{8,9}$ Dendritic cells from $\mathrm{OPG}^{-1-}$ mice present antigens (Ag) more efficiently and produce more inflammatory cytokines under soluble RANKL stimulation than do control DCs from wildtype mice. ${ }^{9}$ Another function of OPG relates to its capacity to bind to TRAIL, which leads to increased cell survival. Apoptosis is stimulated by TRAIL in normal and malignant cells such as endothelial cells, prostate cancer cells, and

\footnotetext{
${ }^{1}$ Centre de Recherche en Rhumatologie et Immunologie, Québec, QC, Canada and ${ }^{2}$ Department of Medicine, Université Laval, Québec, QC, Canada Correspondence: Dr PE Poubelle, MD, DSc, Centre de Recherche en Rhumatologie et Immunologie, CRCHUL, 2705 Blvd Laurier, \#T1-49, Québec, QC, Canada G1V 4G2. E-mail: Patrice.Poubelle@crchul.ulaval.ca 
myeloma cells. ${ }^{10-12}$ TRAIL-induced apoptosis of primary $\mathrm{CD} 4+\mathrm{T}$ cells contributes to human immunodeficiency virus-1 (HIV-1) pathogenesis. ${ }^{13}$ However, TRAIL has also been reported to enhance survival of vascular endothelial cells, and to stimulate proliferation of rheumatoid synoviocytes. ${ }^{14,15}$ In fact, the final outcome of these paradoxical effects of TRAIL has to take into account the possible presence of OPG that acts as a decoy receptor for TRAIL.

Besides its primary function of decoy receptor of RANK-L and TRAIL, OPG can also have agonistic effects. This extracellular protein has been shown to bind to membrane of osteoclasts and to stimulate a pro-matrix metalloproteinase- 9 that requires phosphorylation of mitogen-activated protein kinases. ${ }^{16}$ OPG can also promote the adherence of neutrophils to endothelial cells in vitro and in vivo. ${ }^{17}$ Thus, the simultaneous functions of OPG as a natural decoy receptor and as a cellular stimulus do require a fine regulation for homeostasis. This raises questions on its cellular sources, biosynthesis, availability, and regulation knowing that OPG is a secreted protein only and is present in blood. OPG production is not restricted to bone cells. ${ }^{4}$ Although cytokines, growth factors, hormones, and bioactive lipids are factors capable of modulating this production, studies on its expression and regulation in other cell types are limited. Recently, human peripheral blood mononuclear leukocytes (PBML) have been reported to release OPG. ${ }^{18,19}$ Freshly isolated normal $\mathrm{T}$ cells did not express OPG, whereas fresh T cells from patients with multiple myeloma $\operatorname{did}{ }^{20}$ On the other hand, cultured $\mathrm{T}$ lymphocytes have been shown to inhibit osteoclast activity through an unidentified secreted factor. ${ }^{21,22}$ Together, these data indicate differences of OPG expression between fresh leukocytes isolated from healthy and diseased subjects, and between circulating and infiltrating cells. Note that infiltrating leukocytes are involved in a complex environment of cell-cell, cell-matrix interactions, and factors with stimulatory and inhibitory effects. With this point of view, the autocrine and paracrine activity of OPG could be implicated in the cellular regulation of RANK- and TRAIL-mediated functions.

In the present work, we demonstrate that, among normal human PBML, the CD4 + subset of T lymphocytes is the exclusive immune cell type responsible for OPG formation. We next showed that, in addition to a time-dependent production of OPG by normal $\mathrm{T}$ lymphocytes, a stimulation by anti-CD3 antibody (Ab), interleukin (IL)-4, IL-1 $\beta$, GM-CSF, TNF- $\alpha$, or vitamin $\mathrm{D}_{3}$ upregulated, while IL-10 downregulated, this OPG production. Moreover, conditioned media from nonadherent PBML were capable of decreasing TRAIL-induced apoptosis of human myeloma cells in vitro, an effect that was associated with OPG. Finally, as HIV-1associated diseases are related to compromised CD4 + T-cell functions, ${ }^{23}$ we evaluated the effects of HIV-1 gp120 proteins and proteases inhibitors of highly active antiretroviral therapy (HAART) on the production of $\mathrm{CD} 4+\mathrm{T}$-cell-derived OPG in vitro.

\section{MATERIALS AND METHODS Reagents}

Ficoll-Paque (density at room temperature 1.077), RPMI 1640, and FBS were purchased from Wisent Inc. (St-Bruno, QC, Canada). Human recombinant GM-CSF, IL-4, IL-10, TGF- $\beta$, TNF- $\alpha$, and TRAIL were from Peprotech Inc. (Rocky Hill, NJ, USA). MACS-microbeads conjugated to anti-CD14, -CD19, -CD4, -CD8, and AUTOMACS columns were from Miltenyi Biotec Inc. (Auburn, CA, USA). Trizol reagent, Superscript ${ }^{\mathrm{TM}}$ II Reverse Transcriptase kit and standard markers were from Invitrogen Canada Inc. (Burlington, ON, Canada). Qiagen mRNA purification kit was from Qiagen Inc. (Mississauga, ON, Canada). Oligo-dT primers and Taq DNA polymerase were from PerkinElmer Life and Analytical Science (Woodbridge, ON, Canada). The mouse anti-human OPG capture Ab, goat anti-human OPG detecting Ab, recombinant human OPG (rhOPG), and FITC-conjugated annexin-V were purchased from R\&D Systems Inc. (Minneapolis, MN, USA). Streptavidin horseradish peroxidase (streptavidin-HRP) was obtained from Medicorp. Inc. (Montréal, QC, Canada). Maxisorb microtiter plates were purchased from Nalge Nunc International (Rochester, NY, USA). Recombinant gp120 from HIV-1 $1_{\mathrm{SF} 162}, \mathrm{HIV}-1_{\mathrm{BaL}}$, HIV$1 \mathrm{CM}$, and HIV-1 $1_{96 \mathrm{ZM} 651}$ proteins, and HIV protease inhibitors (PIs) indinavir, nelfinavir, ritonavir, and saquinavir were all obtained through the National Institutes of Health AIDS Research and Reference Reagents Program, Division of AIDS, NIAID, NIH.

\section{Preparation and Culture of Peripheral Blood T Lymphocytes}

All steps of cellular preparations were carried out under sterile conditions at room temperature. The institutional review board of the Universite Laval approved the present study and volunteers signed a consent form. Human venous blood collected on citrate phosphate dextrose adenine anticoagulant solution from healthy donors was diluted $1 / 2$ with HBSS, layered over a Ficoll-Paque cushion, and centrifuged at $400 \mathrm{~g}$ for $20 \mathrm{~min}$ at $20^{\circ} \mathrm{C}$ without brake. The PBML fraction was collected at the interface, and after a first wash in HBSS $(300 \mathrm{~g}, 10 \mathrm{~min})$, platelets were removed by another wash in HBSS $(200 \mathrm{~g}, 10 \mathrm{~min}) .{ }^{24}$ PBML were counted and resuspended in RPMI $1640+10 \%$ FBS. Differential cell counts of leukocytes were performed by fluorescenceactivated cell scanning analysis (FACScan flow cytometer EPICS-XL, Beckman Coulter, Miami, FL) using forward angle and right angle light scatter characteristics and specific fluorescein-conjugated monoclonal anti-CD3 Ab, by Wright's and nonspecific esterase stains. PBML were constituted of 75-85\% lymphocytes and $15-25 \%$ monocytes. Cell viability was routinely assessed by trypan blue dye exclusion test in each experiment after cell separation (greater than $99 \%$ for PBML) and at the time points studied (viability of PBML was about $98 \%$ ). PBML were then subjected to adherence on plastic Petri dishes $\left(5 \times 10^{6}\right.$ cells $\left./ \mathrm{ml}, 37^{\circ} \mathrm{C}, 90 \mathrm{~min}\right)$. 
The nonadherent fraction of PBML was recovered, counted and resuspended in RPMI $1640+10 \%$ FBS. This nonadherent fraction represented $95-99 \%$ CD3 + cells as analyzed by FACScan, and the monocyte contamination was less than $1 \%$ as assessed by nonspecific esterase staining. Possible proliferation of $\mathrm{T}$ cells during the 9 days incubation period was evaluated by using the Alamar Blue test (lot \# 144569 SA, Medicorp. Inc. Montréal, QC, Canada).

The purified cells were resuspended in the incubation medium (RPMI $1640+10 \%$ FBS) at $5 \times 10^{6}$ cells $/ \mathrm{ml}$ in 12 -well plates $(2 \mathrm{ml} /$ well $)$, and incubated at $37^{\circ} \mathrm{C}, 5 \% \mathrm{CO}_{2}$ for up to 9 days. The different conditions of incubation included $500 \mathrm{pM}$ GM-CSF, $10 \mathrm{ng} / \mathrm{ml}$ TNF- $\alpha, 10 \mathrm{ng} / \mathrm{ml} \mathrm{IL-4,} 40 \mathrm{ng} / \mathrm{ml}$ IL- $10,10 \mathrm{ng} / \mathrm{ml}$ TGF- $\beta, 10^{-7} \mathrm{M}$ vitamin $\mathrm{D}_{3}, 10 \mathrm{ng} / \mathrm{ml} \mathrm{IL}-1 \beta$, plastic bound monoclonal anti-CD3 $\mathrm{Ab}$ (anti-CD3 $\mathrm{mAb}$ ), or $500 \mathrm{ng} / \mathrm{ml}$ recombinant HIV-1 gp120 proteins (from four different HIV-1 strains). Recombinant gp120 from HIV$1_{\mathrm{SF} 162}, \mathrm{HIV}-1_{\mathrm{BaL}}, \mathrm{HIV}-1 \mathrm{CM}$, and HIV-1 ${ }_{96 \mathrm{ZM} 651}$ proteins' purity, as determined by SDS-polyacrylamide gel electrophoresis (PAGE) and Coomassie blue staining, was estimated to be $>95 \%$. PIs were prepared as stock solutions in DMSO to obtain a final concentration of DMSO in control or drugtreated cultures that did not exceed $0.1 \%$.

Cells and supernatants were recovered at days 2, 4, 6, and 9. After centrifugation, cell pellets of each well were resuspended in $1.5 \mathrm{ml}$ Trizol for RNA extraction. These preparations and supernatants were frozen at $-20^{\circ} \mathrm{C}$ until assayed. When required (western blot analysis, apoptosis assay), concentrated supernatants of $\mathrm{T}$ lymphocytes were obtained by centrifugation over Centricon Centrifugal Filter Unit with Ultracel YM-100 membrane (Millipore Corp., Billerica, MA, USA) at $5000 \mathrm{~g}$ for $30 \mathrm{~min}$ at $4^{\circ} \mathrm{C}$.

\section{Magnetic Cell Sorting of CD14,+ CD19,+ CD4 + , and CD8 + Subpopulations}

Positive selection of monocytes, B and T lymphocytes was performed by adding magnetic cell sorting (MACS) colloidal superparamagnetic microbeads conjugated with monoclonal anti-human CD14, CD19, CD4 or CD8 antibodies, respectively, to a cooled and freshly prepared PBML or nonadherent PBML (for CD4 + and CD8 + cells) suspension in running buffer (PBS $+5 \mathrm{mM}$ EDTA $+0.5 \%$ BSA) according to the manufacturer's instructions. Cells and microbeads were incubated for $15 \mathrm{~min}$ at $6^{\circ} \mathrm{C}$. Concurrently, the separation column was washed, incubated with MACS buffer. Five milliliters of ice-cold running buffer was added to the cellmicrobead mixture, and cells were gently resuspended. This suspension was loaded onto the magnetic separation AUTOMACS column. The fractions enriched in $\mathrm{CD} 14+$, $\mathrm{CD} 19+, \mathrm{CD} 4+$, or CD8 + cells were eluted with running buffer in fractions of $2 \mathrm{ml}$. Pure CD14+, CD19+, CD4+, and CD8 + cells were washed, counted and resuspended in RPMI $+10 \%$ FBS + streptomycin to be further studied. For controls, pure $\mathrm{T}$ lymphocytes corresponding to $\mathrm{CD} 3+$ cells were obtained from the effluent containing CD19- and
CD14-depleted lymphocytes, washed, and adherence on plastic Petri dishes was carried out as described above to eliminate possible remaining adherent monocytes. Before incubations, purity of enriched subpopulations was assessed by FACScan and was recorded at $94-98 \%$ for CD19+ and CD8 + lymphocytes, at $92 \%$ for CD14 + monocytes and $97 \%$ for CD4 + lymphocytes.

\section{Enzyme Immunometric Assays (EIA)}

OPG was evaluated by using an enzyme immunometric assay at two sites with HRP as tracer. Ninety-six-well plates were coated with a monoclonal anti-human OPG Ab (MAB8051, $\mathrm{R} \& \mathrm{D}$ ) in phosphate buffer solution at $\mathrm{pH}$ 7.4. Sandwiches of $\mathrm{Ag}$ were made possible by using a compatible biotinylated second goat polyclonal anti-human OPG Ab (BAF805, R\&D) in phosphate buffer solution at $\mathrm{pH} 7.4$ containing BSA. Ag$\mathrm{Ab}$ complexes were detected by addition of a streptavidineHRP conjugate which bound to biotinylated antibodies and by addition of tetramethylbenzidine as substrate of HRP. Concentrations of OPG were obtained from a standard curve generated by known concentrations of human recombinant OPG added to the incubation medium. The detection limits were $7.5 \mathrm{pg} / \mathrm{ml}$ for incubation materials, and $15 \mathrm{pg} / \mathrm{ml}$ for plasma samples obtained from heparinized blood samples centrifuged at 1800 r.p.m., $15 \mathrm{~min}, 4^{\circ} \mathrm{C}$. Interleukin- 2 was measured by EIA with acetylcholine esterase as label and a detection limit of $5 \mathrm{pg} / \mathrm{ml} .^{25} \mathrm{IL}-4$ was assessed by using the R\&D human IL-4 Quantikine HS kit (\# HS400) with HRP as tracer and detection limit of $32 \mathrm{pg} / \mathrm{ml}$.

\section{RNA Extraction and Purification}

Total RNA was isolated from cells using Trizol reagent following the manufacturer's instructions. RNA isolation was obtained by chloroform extraction, isopropanol precipitation, and one ethanol washing. Briefly, $10^{7}$ PBML were homogenized in $1 \mathrm{ml}$ Trizol. After mixing with $200 \mu \mathrm{l}$ chloroform, samples were centrifuged for $15 \mathrm{~min}$ at $10000 \mathrm{~g}$ $\left(4^{\circ} \mathrm{C}\right)$, the upper aqueous phase was recovered and added to an equal volume of isopropanol. Mixtures were thoroughly vortexed and centrifuged $10 \mathrm{~min}$ at $12000 \mathrm{~g}\left(4^{\circ} \mathrm{C}\right)$. The precipitated RNA pellets were washed with $1 \mathrm{ml}$ ethanol $(70 \%, \mathrm{v} / \mathrm{v})$. RNA pellets were recovered after centrifugation for $5 \mathrm{~min}$ at $120000 \mathrm{~g}$ and were allowed to air-dry for 2-3 min before being resuspended in DEPC-treated water. The integrity of total RNA samples was evaluated by running them on a $1 \%$ agarose gel electrophoresis followed by ethidium bromide staining. RNA was quantitated by UV absorbance at $260 \mathrm{~nm}$. For northern blot analysis, poly- ${ }^{+}{ }^{+}$RNA was purified from total RNA using a Qiagen mRNA purification kit according to the manufacturer's specifications.

\section{Northern Blot Analysis}

Poly-A ${ }^{+}$RNA was migrated on an agarose/formaldehyde gel and transferred onto a nylon filter (Hybond-XL) using a Vacugene transfer apparatus (Amersham Pharmacia Biotech, 
Inc.). RNA was fixed by a UV-crosslinker as specified by the manufacturer. Filters were hybridized with a $2.4 \mathrm{~kb}$ human $O P G$ cDNA probe labeled with $\left[\alpha_{-}{ }^{32} \mathrm{P}\right] \mathrm{dCTP}$ using Neblot kit (New England BioLabs Inc.). Bands were revealed and analyzed with a BAS-1800 bioimaging analyzer.

\section{Western Blot Analysis}

To confirm appropriate expression of OPG, supernatants of T lymphocytes incubated in the presence of anti-CD3 + IL-4 were analyzed by western blotting. Proteins of supernatants were concentrated by centrifugation over membranes with $100 \mathrm{kDa}$ cut-off, were solubilized in SDS sample buffer, and were separated by a 10\% SDS-PAGE under nonreducing conditions at $150 \mathrm{~V}$ (Miniprotean II equipment, Bio-Rad Laboratories Ltd, Mississauga, ON, Canada). Biotinylated dual-color protein standards were used as molecular weight marker. The proteins were transferred to a PVDF membrane in a semidry blotter (Bio-Rad) at $5.5 \mathrm{~mA} / \mathrm{cm}^{2}$ and $15 \mathrm{~V}$ at $4{ }^{\circ} \mathrm{C}$ for $90 \mathrm{~min}$ in transfer buffer, Tris Glycin containing 20\% methanol and $0.2 \%$ SDS. The membrane was blocked with $5 \%$ dry milk in TBS-Tween for $60 \mathrm{~min}$ at room temperature, and analyzed by immunoblotting with $1 \mu \mathrm{g} / \mathrm{ml}$ of rabbit antihuman OPG IgG Ab in the blocking solution for $60 \mathrm{~min}$. The membrane was then washed three times with TBS-Tween and incubated with 1:20000 diluted goat anti-rabbit HRP conjugate in TBS-Tween for $45 \mathrm{~min}$. After three successive washing steps in TBS-Tween of $15 \mathrm{~min}$ each, the proteins were detected by the ECL (enhanced chemiluminescence) detection system (GE Healthcare) and visualized on Kodak Blue XB-1 film (Eastman Kodak, Rochester, NY, USA). To ascertain the identity of bands immunoblotted by the rabbit anti-human OPG IgG, a competition assay was performed. Full-length recombinant OPG protein (R\&D Systems) was incubated overnight with the $\mathrm{Ab}$ at $4{ }^{\circ} \mathrm{C}$ (peptide- $\mathrm{Ab}$ ratio $5: 1$ ). Western blotting was performed in the presence of $A b$ alone and in the presence of the OPG-neutralized $\mathrm{Ab}$.

\section{Apoptosis Assay}

OPG is a decoy receptor for TRAIL and a survival factor for human myeloma cells. ${ }^{1,12}$ The RPMI 8226 myeloma cells (CCL-155, ATCC, Manassas, VA, USA) were cultured in RPMI $1640+10 \%$ heat-inactivated FBS and plated at a density of $1 \times 10^{6}$ cells $/ \mathrm{ml}$ into 96 -well plates (Nalge Nunc International. Rochester, NY, USA). A dose-response effect of TRAIL on apoptosis of RPMI 8226 cells was performed using $1-100 \mathrm{ng} / \mathrm{ml}$ rhTRAIL or vehicle control (PBS) added to the incubation medium. To evaluate whether supernatants of cultured $\mathrm{T}$ lymphocytes contained functional OPG, additional experiments with RPMI 8226 myeloma cells were carried out using $20 \mathrm{ng} / \mathrm{ml}$ rhTRAIL with the simultaneous addition of $15 \mathrm{ng} / \mathrm{ml}$ rhOPG as a positive control, or 25 and $50 \%$ conditioned media from $\mathrm{T}$ lymphocytes (stimulated with $10 \mathrm{ng} / \mathrm{ml} \mathrm{IL-4}$ for 6 days). Conditioned media were concentrated supernatants from $\mathrm{T}$ lymphocytes (pool of three separate donors) obtained as described above to elim- inate IL-4 and other low molecular weight proteins. Further, to verify that the antiapoptotic effect of T-cell supernatants was related to OPG, the above conditioned medium was added to RPMI 8226 cells with or without a five-fold excess of rhRANKL. After $24 \mathrm{~h}$ of incubation, apoptosis of RPMI 8226 cells was evaluated by FITC-labeled annexin-V together with propidium iodide (PI). Briefly, RPMI 8226 cells were centrifuged and resuspended in $500 \mu \mathrm{l}$ of $1 \times$ binding buffer. Five microliter of FITC-labeled annexin-V and PI were added to cells. After a $5 \mathrm{~min}$ incubation at room temperature in the dark, 10000 cells were analyzed by cytofluorometry. Cell mortality was calculated as the number of cells that were stained by FITC-labeled annexin-V or PI.

\section{Plasma from HIV-Infected Individuals}

Plasma samples from 29 HIV-infected subjects were evaluated. Of the $29 \mathrm{HIV}$-infected individuals, 26 were receiving HAART including PIs at the time of sampling. Eighteen subjects (median age of 47 years) had a CD4 + T-cell count $<200$ cells $/ \mathrm{mm}^{3}$ (median of $109 \mathrm{CD} 4+\mathrm{cell} / \mathrm{mm}^{3}$ ) with a median plasma HIV viral load of 18870 HIV RNA copies/ml. The remaining 11 subjects (median age of 46 years) had CD4 + T-cell counts above 200 (median of 280 CD4 + T cells $/ \mathrm{mm}^{3}$ ) with a median HIV load $<50$ HIV RNA copies $/ \mathrm{ml}$.

\section{Statistics}

Values were expressed as means \pm standard error of the mean (SEM) of $n$ experiments performed with cells from different donors. Statistical analyses were performed using GraphPad Instat 3.0 (GraphPad Software, Inc., San Diego, CA, USA). Paired groups were analyzed using the paired $t$-test. Significance was set at a two-tailed $P$-value of less than 0.05 .

\section{RESULTS \\ CD4 + T Lymphocytes are Responsible for the Secretion of OPG}

The first series of experiments was aimed at comparing the OPG production by PBML to that of nonadherent and adherent PBML. The secretion of OPG can be entirely attributed to the nonadherent fraction of PBML (Figure 1a). This production increased from day 2 to day 9 of incubation. OPG reached a plateau after 9 days of incubation to decrease at 12 days (data not shown). Nonadherent PBML alone generated significantly more OPG at day 9 than the whole population of PBML ( $40 \mathrm{pg} / \mathrm{ml} / 10^{6}$ nonadherent cells instead of $31 \mathrm{pg} /$ $\mathrm{ml} / 10^{6}$ nonadherent + adherent PBML considering that adherent PBML corresponded to $10 \%$ of the whole fraction, $P<0.05$ ). Could the time-dependent production of OPG by nonadherent PBML be related to a possible cellular multiplication? As evaluated by three different methods (hemacytometer, FACScan, and Alamar Blue), no significant differences in cell numbers were observed between days 2 and 9 of incubation $(n=6)$. Moreover, the endogenous production of IL-2, a cytokine required for T-cell proliferation, 

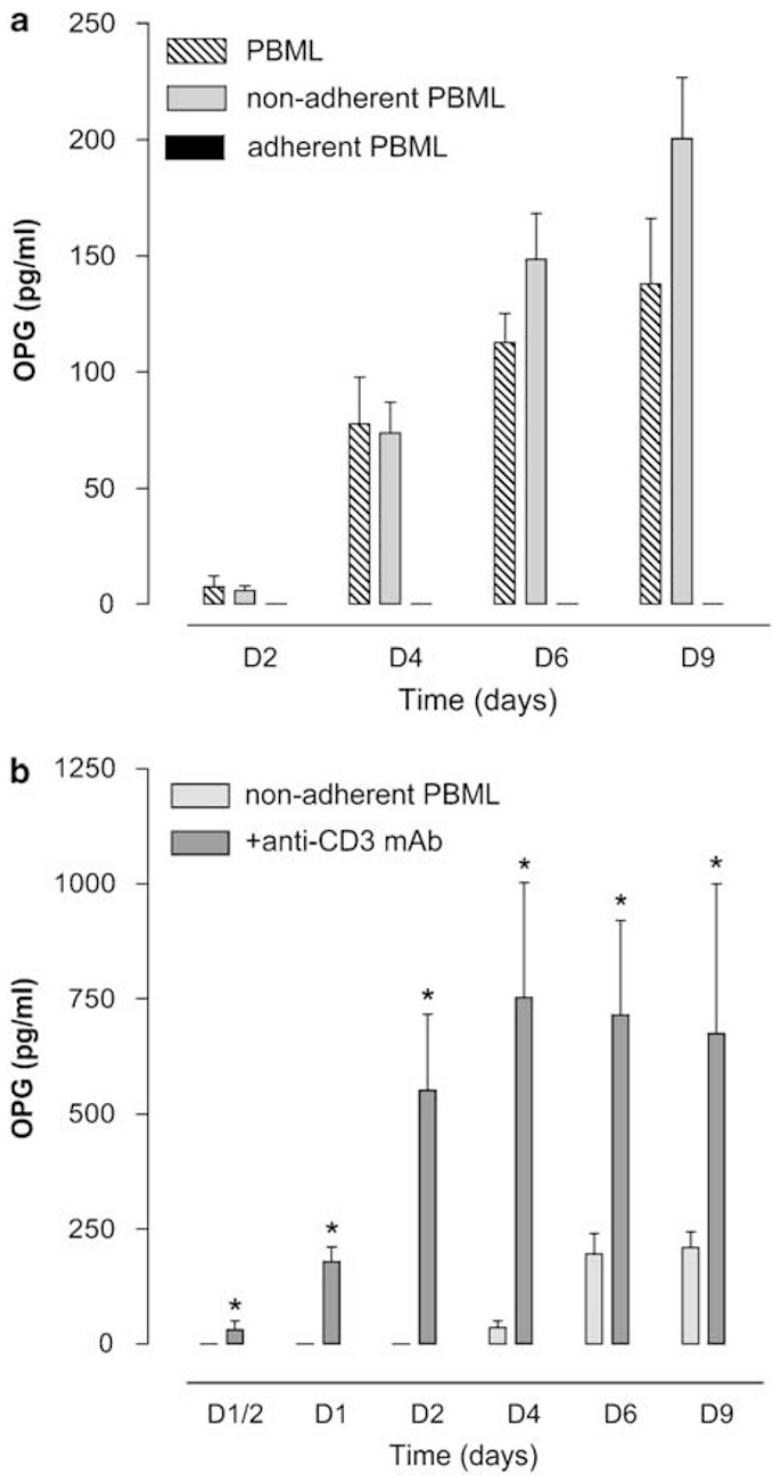

Figure 1 Production of OPG by normal human nonadherent and adherent PBML. (a) Peripheral blood mononuclear leukocytes (PBML), nonadherent and adherent fractions of these PBML were incubated at $5 \times 10^{6} / \mathrm{ml}$ in RPMI $1640+10 \%$ FBS for 9 days; supernatants were successively collected to evaluate the accumulation of OPG by EIA. Results are expressed as means \pm s.e.m. (PBML: $n=6$, nonadherent PBML: $n=15$, adherent PBML: $n=5)$. (b) Nonadherent PBML $\left(5 \times 10^{6} / \mathrm{ml}\right)$ were incubated in RPMI $1640+10 \% \mathrm{FBS}$ at $37^{\circ} \mathrm{C}$ for 9 days in the presence of $10 \mu \mathrm{g} / \mathrm{ml}$ anti-CD3 $\mathrm{mAb}$ coated to plastic. Results are expressed as means \pm s.e.m. $(n=5)$. Statistics: paired two-tailed $t$-test, ${ }^{*} P<0.05$.

peaked at day 4 of incubation ( $127 \pm 47 \mathrm{pg} / \mathrm{ml}$; not shown) to decrease thereafter, a pattern different to that of OPG secretion. The production of IL-4, a cytokine that can stimulate the production of OPG (see below), was also evaluated and was not detected in the supernatants of PBML incubated for up to 9 days $(n=4)$.

Are nonadherent human PBML (mainly $\mathrm{T}$ cells, as measured by FACScan: $90-98 \%$ CD3 + cells) able to increase their synthesis of OPG in response to a pan-T-cell stimulus? An anti-CD3 mAb (clone OKT-3 with no effect on proliferation) coated to plastic stimulated the production of OPG by normal nonadherent PBML. OPG was detected in supernatants as early as $12 \mathrm{~h}$ after stimulation, with a maximum of 20 times the control production after 4 days of stimulation (Figure 1b). This effect was associated with no significant differences of cell numbers (evaluated as above). Note that nonadherent PBML incubated in RPMI 1640 alone also produced OPG over 9 days, but to a lesser extent than in the presence of $10 \%$ FBS (data not shown).

To identify the relative contribution of the different subsets present in PBML, we next investigated the expression of OPG by PBML subpopulations that were purified by immunomagnetic separation to obtain $\mathrm{CD} 4+$ ( $\mathrm{T}$ helper lymphocytes), CD8 + (T suppressor lymphocytes), CD14+ (monocytes), and CD19+ (B lymphocytes) cells. Among enriched subpopulations of $\mathrm{CD} 4+, \mathrm{CD} 8+, \mathrm{CD} 19+$, and $\mathrm{CD} 14+$ blood mononuclear leukocytes, the production of OPG was restricted to the CD4 $+\mathrm{T}$ lymphocytes (Figure 2a). The CD4-positive subset of PBML strongly responded to the anti-CD3 $\mathrm{mAb}$ (Figure $2 \mathrm{~b}$ ). The weak production of OPG by the CD4-negative subpopulation (mainly detected in antiCD3 mAb-stimulated cells) could be related to the small percentage of contaminating CD4 + cells $(1.2 \%)$. The dimeric form of OPG $(110 \mathrm{kDa})$ was the major product released by T cells (Figure 2c, lane 1). To confirm the identity of the band immunoblotted by the rabbit anti-human OPG Ab, competition with a recombinant OPG protein was carried out that led to the disappearance of the specific band of $110 \mathrm{kDa}$ (Figure 2c, lane 2). In addition, northern blotting of polyA ${ }^{+}$RNA isolated from normal human blood $\mathrm{T}$ lymphocytes was conducted in parallel to MG63 osteosarcoma cells that constitutively express $O P G$ mRNA. Hybridization of polyA + RNA of MG63 cells yielded one major $2.4 \mathrm{~kb} O P G$ transcript, consistent with previous reports (Figure $2 \mathrm{~d}$, lane 1). ${ }^{8,26}$ However, polyA + RNA from $\mathrm{T}$ lymphocytes hybridized with the same $O P G$ probe revealed four transcripts of $4.0,2.4,2.2$, and $1.3 \mathrm{~kb}$, the latter being overexpressed relative to the others (Figure $2 \mathrm{~d}$, lane $\mathrm{T}$ cells). The 4.0 and 2.4 splice variants have been previously detected in various tissues and somewhat characterized. ${ }^{26}$ However, the most abundantly expressed 2.2 and $1.3 \mathrm{~kb} O P G$ mRNA detected in T cells are newly identified transcripts suggesting that the OPG transcripts splicing patterns differ between tissues.

\section{OPG Produced by T Lymphocytes is Differently Regulated by Cytokines}

The next step was to examine how $\mathrm{T}$ lymphocyte-derived OPG might be regulated by various factors of pathophysiological significance. In this series of experiments, normal human blood $\mathrm{T}$ lymphocytes were cultured for up to 9 days in the presence or absence of optimal concentrations of selected autacoids. Factors such as IL- $1 \beta$, GM-CSF, TNF- $\alpha$, or vitamin $\mathrm{D}_{3}$ induced a slight, but significant, increase of OPG 

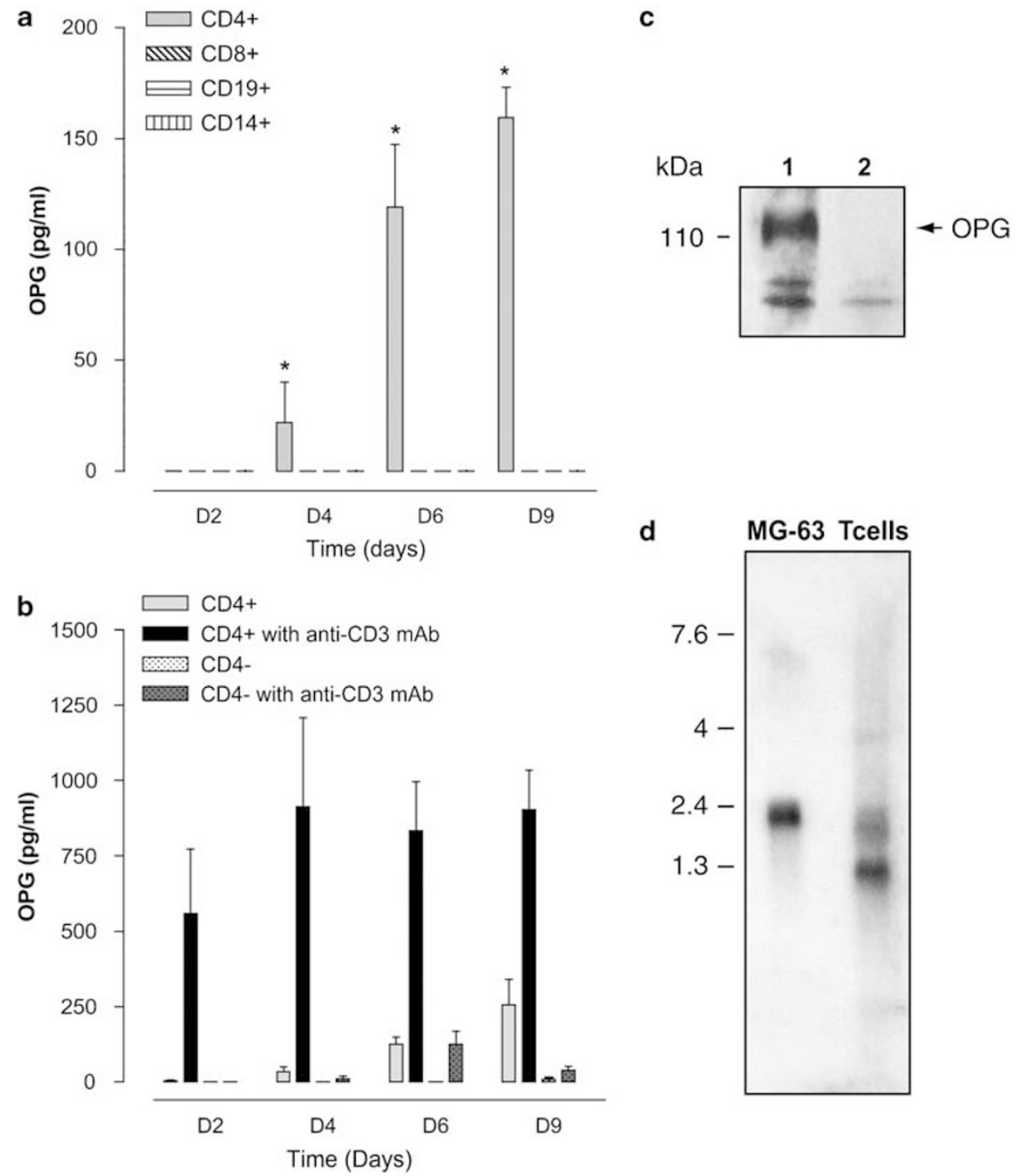

Figure 2 Production of OPG by normal human PBML subpopulations. (a) PBML were subjected to positive immunomagnetic isolation using CD4-, CD8-, CD19-, and CD14-conjugated magnetic beads. The PBML subpopulations $\left(5 \times 10^{6} / \mathrm{ml}\right)$ were incubated in RPMI $1640+10 \%$ FBS for 9 days, and supernatants were successively collected at days $2,4,6$, and 9 to evaluate the accumulation of OPG by EIA. Results are expressed as means \pm s.e.m. ( $n=3$ ), and statistics used the paired two-tailed $t$-test, ${ }^{*} P<0.05$. (b) Normal human nonadherent PBML were separated by using CD4-conjugated magnetic beads. CD4-positive and CD4-negative subpopulations $\left(5 \times 10^{6} / \mathrm{ml}\right)$ were incubated in RPMI $1640+10 \%$ FBS for 9 days in the presence of $10 \mu \mathrm{g} / \mathrm{ml}$ anti-CD3 $\mathrm{mAb}$ coated to plastic, and supernatants were successively collected at days 2, 4, 6, and 9 to evaluate the accumulation of OPG by EIA. Results are expressed as means \pm s.e.m. $(n=3)$. (c) Supernatants of normal human nonadherent PBML stimulated by plastic bound anti-CD3 mAb and IL-4 for 6 days were subjected to western blot analysis. Supernatants were collected, concentrated over centrifugal filter device (100 kDa membrane cut-off), and proteins were solubilized, separated by SDS-PAGE in nonreducing conditions, immunoblotted with a rabbit anti-human OPG IgG without (lane 1) or with a pretreatment with the recombinant protein OPG (lane 2), revealed by a goat anti-rabbit HRP conjugate detected by the ECL system. The western blot presented is representative of two different normal subjects. (d) Poly- ${ }^{+}$-rich RNA $(10 \mu \mathrm{g})$ obtained from total RNA of MG-63 cells (lane 1) and normal human nonadherent PBML stimulated by anti-CD3 mAb + IL-4 (lane 2) was analyzed by northern blotting with a ${ }^{32} \mathrm{P}$-labeled OPG CDNA probe.

production by $\mathrm{T}$ lymphocytes after 6 days of incubation (Table 1). The percentages of increase ranged from 129 to $147 \%$. In contrast, TGF- $\beta$, known to augment OPG synthesis in osteoblasts, had no influence on the OPG production by $\mathrm{T}$ lymphocytes, even used at 10 times the optimal dose (data not shown).

Th2-type cytokines, like IL-4 and IL-10, have been shown to reduce bone resorption through mechanisms of action that could implicate OPG. ${ }^{27,28}$ As shown in Figure 3a, IL-4 significantly increased the basal output of OPG produced by normal T cells at day $2,4,6$, and $9(1100,240,170$, and $210 \%$ of matched controls, respectively). However, IL-10 inhibited the formation of OPG by $\mathrm{T}$ cells (Figure $3 \mathrm{~b}$ ). A significant inhibition of the time-dependent production of OPG was obtained at day 4, 6, and $9(63,62$, and 54\% inhibition of matched controls, respectively). Moreover, the addition of 
Table 1 Effects of autacoids on the production of OPG by normal human blood T lymphocytes

\begin{tabular}{|c|c|c|c|c|}
\hline Autacoids & D-2 & D-4 & D-6 & D-9 \\
\hline IL-1 $\beta, 600 \mathrm{pM}$ & $28 \pm 12(3 \pm 2)$ & $77 \pm 27(62 \pm 40)$ & $172 \pm 56^{*}(134 \pm 48)$ & $246 \pm 76^{*}(188 \pm 56)$ \\
\hline TNF- $\alpha, 600$ pM & $10 \pm 4(11 \pm 5)$ & $68 \pm 16(81 \pm 17)$ & $117 \pm 13(94 \pm 10)$ & $144 \pm 20^{*}(112 \pm 24)$ \\
\hline GM-CSF, +TNF- $\alpha$ & $26 \pm 14(11 \pm 6)$ & $89 \pm 18(72 \pm 20)$ & $125 \pm 13^{*}(87 \pm 8)$ & $137 \pm 21^{*}(93 \pm 18)$ \\
\hline TGF- $\beta, 400$ pM & $18 \pm 10(13 \pm 6)$ & $107 \pm 30(87 \pm 19)$ & $153 \pm 25(146 \pm 22)$ & $262 \pm 39(251 \pm 43)$ \\
\hline
\end{tabular}

Nonadherent PBML $\left(5 \times 10^{6} / \mathrm{ml}\right)$ were incubated in RPMI 1640+10\% FBS with addition of factors for 9 days and the supernatants collected at days (D) 2, 4, 6 , and 9 . Measurement of OPG was performed by EIA and results were expressed in $\mathrm{pg} / \mathrm{ml}$. Values represent means \pm s.e.m. $(n=6$ for the first four conditions; $n=7$ for vitamin $\mathrm{D} ; n=5$ for TGF- $\beta$ ). Values in parentheses correspond to matched controls. Statistics: paired two-tailed $t$-test, ${ }^{\star} P<0.05$.

IL-10 to the cells incubated in the presence of IL-4 drastically decreased both basal and inducible productions of OPG (Figure 3c). At day 2, IL-10 completely abrogated the generation of OPG and then inhibited significantly the accumulation of OPG at day 4,6 , and 9 (83, 86, and $93 \%$ inhibition of the IL-4-induced production, respectively).

\section{Conditioned Media from Normal Human Blood T Lymphocytes have Survival Effects on TRAIL-Induced Apoptosis of RPMI 8226 Myeloma Cells}

OPG is a decoy receptor for TRAIL, a protein that induces apoptosis of RPMI 8226 myeloma cells in vitro. ${ }^{1,12}$ The next series of experiments evaluated the effects of conditioned media from $\mathrm{T}$ lymphocytes on apoptosis of RPMI 8226 myeloma cells in the presence of exogenous TRAIL. As shown in Figure 4a, recombinant human TRAIL induced a dosedependent apoptosis of RPMI 8226 cells. After $24 \mathrm{~h}$ in the presence of 1 or $500 \mathrm{ng} / \mathrm{ml}$ of rhTRAIL, survival of RPMI 8226 cells was $61.2 \pm 6.8$ or $3.4 \pm 0.4 \%$, respectively. Addition of recombinant human OPG $(15 \mathrm{ng} / \mathrm{ml})$ inhibited TRAILinduced apoptosis (Figure 4b). Moreover, conditioned medium from $\mathrm{T}$ lymphocytes (containing $9.6 \mathrm{ng} / \mathrm{ml} \mathrm{OPG}$ ) significantly inhibited apoptosis of rhTRAIL-treated RPMI 8226 cells when added by half of the incubation volume (Figure $4 \mathrm{~b}$ ). The affinity of RANKL to bind to OPG is 30 times higher than that of TRAIL for OPG. ${ }^{1,29}$ Thus, RANKL, added at an appropriate concentration to conditioned medium from T lymphocytes, would bind preferentially to OPG. The consequence would be a net loss of OPG activity in parallel to a persistent activity of TRAIL. As shown in Figure $4 c$, an excess of rhRANKL significantly affected the increased survival of RPMI 8226 myeloma cells in the presence of T-cell conditioned medium $(43 \pm 2$ and $61 \pm 5 \%$ with or without RANKL, respectively), whereas rhRANKL alone did not affect cell viability. Thus, OPG present in conditioned medium from $\mathrm{T}$ lymphocytes functioned as a survival factor for RPMI 8226 myeloma cells incubated in the presence of TRAIL.
The Production of OPG by Normal Human Blood CD4 + T Lymphocytes is Inhibited by HIV-1 gp120 Proteins and by PIs

HIV-induced disease is associated with a CD4 + dysfunction. ${ }^{23}$ In addition, CD4 + T lymphocytes targeted by gp 120 is fundamental to the pathogenesis of AIDS. ${ }^{30,31}$ Having established that CD4 + lymphocytes, among human PBML, were the essential source of functional OPG, the next series of experiments were devoted to the study of the effects of HIV-1 gp120 proteins on the production of OPG by normal $\mathrm{T}$ cells. As shown in Figure 5a, the recombinant gp120 from different HIV-1 strains significantly diminished the basal output of OPG generated by blood $\mathrm{T}$ cells from three healthy subjects. A significant reduction of OPG production was observed from day 4 to day 9 of incubation. Among the four strains tested, gp120 from HIV-1 $1_{\mathrm{BaL}}$, HIV-1 CM, and HIV-1 $1_{\mathrm{SF} 162}$ proteins inhibited the OPG production by $\mathrm{CD} 4+\mathrm{T}$ lymphocytes, while gp120 from HIV-1 $1_{96 \mathrm{ZM} 651}$ did not (Figure $5 b)$. The concentration-dependent inhibition was maximal at $500 \mathrm{ng} / \mathrm{ml}$ of gp 120 proteins at day $9(48,76$, and $56 \%$ inhibition, respectively). No effect on cell viability was observed (not shown).

Certain PIs linked to osteopenia, such as ritonavir and saquinavir, have been shown to interfere with RANKL activity from T cells. ${ }^{32}$ In addition to the HIV-1 gp120-induced inhibition of OPG production by $\mathrm{T}$ cells, could PIs directly modulate T-cell synthesis of OPG? The effects of four different PIs that are constituents of HAART (indinavir, nelfinavir, ritonavir, and saquinavir) were studied on the basal production of OPG by $\mathrm{T}$ lymphocytes from three healthy donors. A dose-response effect $(1,5,10 \mu \mathrm{M})$ for each of the four PIs indicated that $10 \mu \mathrm{M}$ was the optimal concentration to use without alteration of T-cell viability (data not shown). The four PIs decreased the basal production of OPG by $\mathrm{T}$ cells. Nelfinavir and ritonavir were the most effective compounds that inhibited the basal output of OPG at day 9 of incubation (Figure 6a). Similar results were obtained with total $\mathrm{T}$ cells from nonadherent PBML or with $\mathrm{CD} 4+\mathrm{T}$ 
lymphocytes purified by immunomagnetic isolation (Figure 6b). Individually, HIV-1 gp120 proteins or PIs decreased the basal output of OPG production by $\mathrm{T}$ cells. Could the
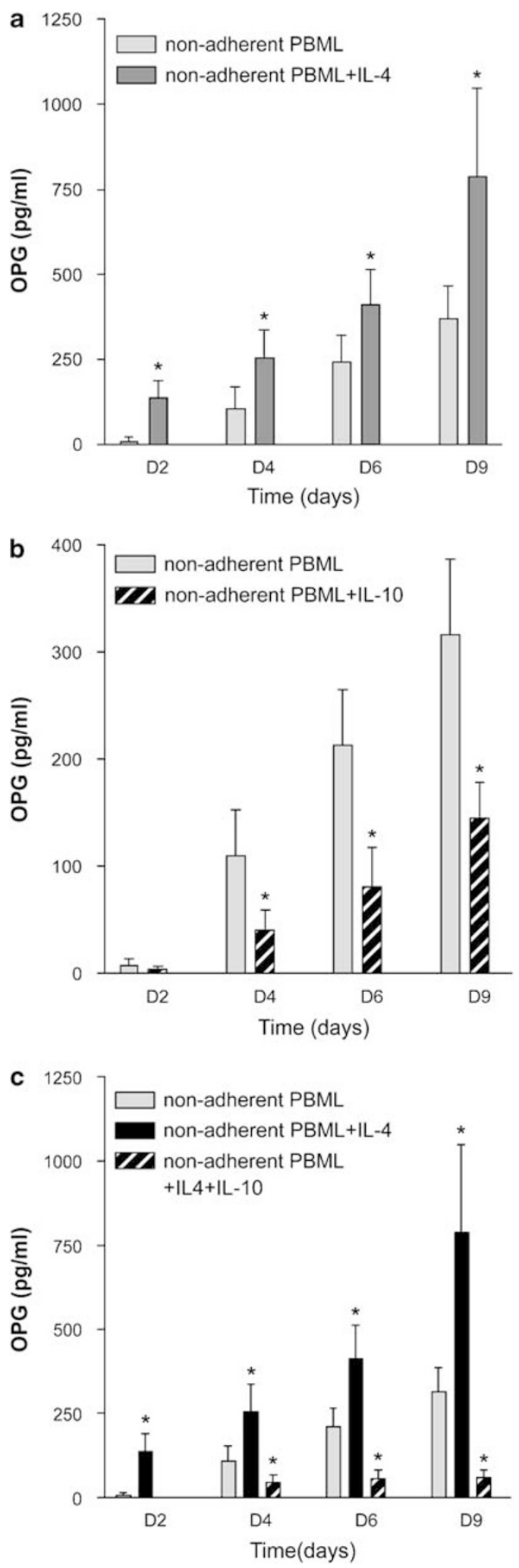

simultaneous presence of HIV-1 gp120 and a PI additively affect T-cell production of OPG? As ritonavir was already associated with ostepenia and was found to impact on $\mathrm{T}$ cells, ${ }^{32}$ the next series of experiments were carried out with this PI. Incubation of T cells in the presence of HIV-1 gp120 and ritonavir resulted in the abrogation of OPG production at day 4, and a strong inhibition at days 6 and 9 (84 and 87\%, respectively; Figure 6a).

Finally, plasma concentrations of OPG from 29 HIV-infected individuals (26/29 received HAART) were retrospectively evaluated and were significantly lower $(209 \pm 23 \mathrm{pg} / \mathrm{ml})$ than plasma OPG concentrations of 62 age-matched controls $(502 \pm 50 \mathrm{pg} / \mathrm{ml})$.

\section{DISCUSSION}

The biological activity of OPG has been predominantly studied in two receptor-ligand systems, which are the OPG/ RANKL/RANK and the OPG/TRAIL(APO2)/TRAILR molecular systems. Thus, OPG was first identified as a factor that inhibits the development and activity of osteoclasts by binding to RANKL., ${ }^{2,4}$ OPG was then showed to block TRAIL-induced apoptosis and, interestingly, binding of OPG to TRAIL abrogated its anti-osteoclastogenic activity. ${ }^{1}$ A hallmark of chronic inflammatory reactions is the prolonged presence of tissue-activated $\mathrm{T}$ lymphocytes involved in disease-specific lesions. Deleterious consequences of such T cells have been demonstrated by using a rat model of adjuvant arthritis. Activation of $\mathrm{T}$ cells in vivo induced an RANKLmediated increase of osteoclastogenesis and bone resorption. ${ }^{6}$ Similarly, T lymphocytes activated by human myeloma cells have been associated with an RANKL-stimulated osteoclastogenesis and bone destruction. ${ }^{33}$ Moreover, autoimmune colitis associated with spontaneous osteopenia has been linked with an increased production of RANKL by autoreactive $\mathrm{CD} 4+\mathrm{T}$ cells. ${ }^{34}$ The present demonstration of spontaneous and inducible OPG production by $\mathrm{CD} 4+\mathrm{T}$ lymphocytes in culture could represent a physiological mechanism to compensate, at least in part, the consequences of increased RANKL. It is of note that CD4 + T-cell-derived OPG efficiently functions to neutralize exogenous TRAIL responsible for apoptosis of RPMI 8226 myeloma cells (Figure 4b). Moreover, the specificity of OPG inhibition of RPMI 8226 apoptosis was confirmed by the neutralization of this effect after addition of exogenous RANKL (Figure 4c). The compensatory effect of OPG from T cells, though important for homeostasis and physiological inflammation,

Figure 3 Effects of IL-4 and IL-10 on the production of OPG by normal human blood T lymphocytes. The nonadherent fraction of PBML $\left(5 \times 10^{6} \%\right.$ $\mathrm{ml}$ ) resuspended in incubation medium were incubated at $37^{\circ} \mathrm{C}$ for 9 days in the presence of $10 \mathrm{ng} / \mathrm{ml} \mathrm{IL-4}(\mathbf{a}), 40 \mathrm{ng} / \mathrm{ml} \mathrm{IL-10}(\mathbf{b})$, or $10 \mathrm{ng} / \mathrm{ml} \mathrm{IL-}$ $4 \pm$ the simultaneous presence of $40 \mathrm{ng} / \mathrm{ml} \mathrm{IL-10}$ (c). Supernatants were successively collected at days $2,4,6$, and 9 to evaluate the accumulation of OPG by EIA. Results are expressed as means \pm s.e.m. $(n=5)$. Statistics: paired two-tailed $t$-test, ${ }^{\star} P<0.05$. 
might be overridden in chronic disease conditions. For instance, although myeloma $\mathrm{T}$ lymphocytes released high levels of RANKL, OPG, and TRAIL, OPG was shown to be inactivated by its binding to TRAIL. ${ }^{20}$ OPG and TRAIL are also expressed by cells from prostate and breast cancers where OPG is a survival factor through inhibition of TRAIL-induced apoptosis of tumor cells. ${ }^{10,35}$ Inversely, the decrease
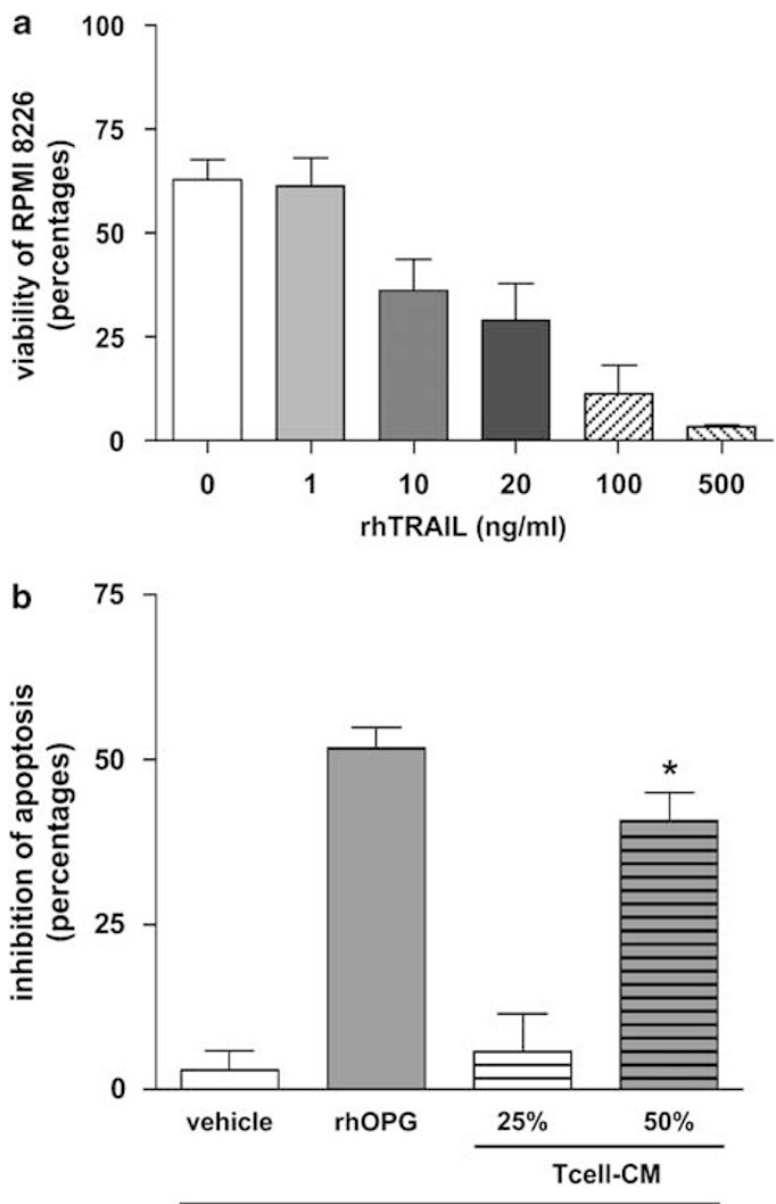

+ rhTRAIL $(20 \mathrm{ng} / \mathrm{ml})$

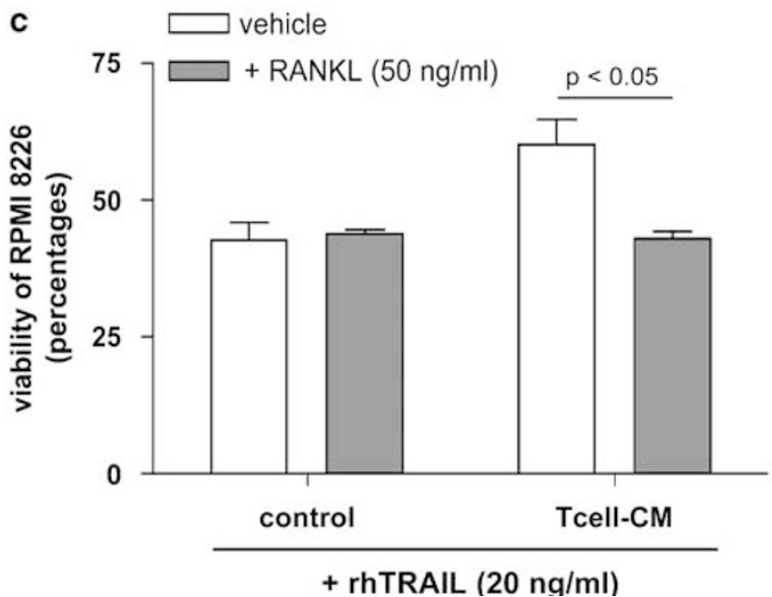

of OPG production by $\mathrm{T}$ cells induced by causal factors of certain pathologies could be a factor of enhancement of the local abnormal response. This condition of aggravation is suggested by our data that showed a strong reduction in T-cell synthesis of OPG by HIV-1 gp120 proteins and PIs.

The conditions of synthesis of OPG by T cells are different from those of RANKL and TRAIL. T cells do not produce RANKL and TRAIL spontaneously, and their activation is a prerequisite to generate these factors. ${ }^{6,36-38}$ On the other hand, $\mathrm{T}$ cells in culture were shown to have a time-dependent production of a basal output of OPG without any stimulus (Figure 1a), production that increased in the presence of various stimuli (Figure 1b, Table 1). Our data suggest an auto and paracrine role of OPG produced by $\mathrm{T}$ cells to maintain homeostasis and to counterbalance the production of RANKL and TRAIL by activated T cells. Moreover, the production of OPG by T cells is restricted to CD4 + lymphocytes (Figure 2a), a pattern different from that of RANKL and TRAIL, which are both produced by $\mathrm{CD} 4+$ and CD $8+$ cells. ${ }^{37,39,40}$ In 1990, Fujita et $a l^{41}$ already reported that high blood CD4 + was associated with low osteoclastic bone resorption. Activated $\mathrm{T}$ cells have the capacity to suppress osteoclastogenesis through the production of IFN- $\gamma$ which interferes with the RANKL-RANK signaling pathway by activation of TRAF6 degradation. ${ }^{42}$ Moreover, CD4 +, but not $\mathrm{CD} 8+\mathrm{T}$ lymphocytes, are the cell type responsible for the production of osteoclastogenesis inhibitory cytokines such as IFN- $\gamma$ and GM-CSF. ${ }^{43}$ Our present data add to T-cell-derived anti-osteoclastogenesis factors generated by $\mathrm{CD} 4+$ lymphocytes the production of OPG, which can be strongly increased depending on the stimulus (Figure 1b, Table 1). This is particularly relevant when referring to variability of the effects of $\mathrm{T}$ cells on osteoclastogenesis in vitro, a phenomenon that essentially depends on the conditions of lymphocyte stimulation. ${ }^{44}$ It is also interesting to note that the production of OPG by lymphocytes differs depending on the species. Our data indicate that human B lymphocytes (purified as

Figure 4 OPG and conditioned media from T lymphocytes inhibit TRAILinduced apoptosis of RPMI 8226 myeloma cells. RPMI 8226 myeloma cells $\left(1 \times 10^{6}\right.$ cells $\left./ \mathrm{ml}\right)$ were treated with graded concentrations of rhTRAIL $(1-500 \mathrm{ng} / \mathrm{ml})$. Viable cells were evaluated after $24 \mathrm{~h}$ of incubation at $37^{\circ} \mathrm{C}$ by FACScan analysis. Results $(n=3)$ are expressed as percentages of cells unstained by Annexin-V and propidium iodide (a). Inhibition of rhTRAILinduced apoptosis in RPMI 8226 myeloma cell line by rhOPG and conditioned medium of T lymphocytes. RPMI 8226 cells $\left(1 \times 10^{6}\right.$ cells $\left./ \mathrm{ml}\right)$ were treated with $20 \mathrm{ng} / \mathrm{ml}$ rhTRAlL in the absence or presence of $15 \mathrm{ng} / \mathrm{ml}$ rhOPG, 25 or $50 \%$ of conditioned medium from T lymphocytes (Tcell-CM). After concentration of pooled supernatants from three different donors, Tcell-CM contained $9.6 \mathrm{ng} / \mathrm{ml}$ of OPG, as measured by EIA. Results are expressed as percentages of inhibition of TRAIL-induced apoptosis of RPMI 8226 cells (mean \pm s.e.m. of three independent experiments). Statistics: paired $t$-test (OPG or Tcell-CM vs vehicle); ${ }^{*} P<0.05$ (b). RPMI 8226 myeloma cells $\left(1 \times 10^{6}\right.$ cells $\left./ \mathrm{ml}\right)$ were incubated with $50 \%$ of Tcell-CM in the absence or presence of $50 \mathrm{ng} / \mathrm{ml}$ recombinant human RANKL. Results $(n=3)$ are expressed as percentages of cells unstained by Annexin- $V$ and propidium iodide. Statistics: paired $t$-test (Tcell-CM + RANKL vs vehicle); ${ }^{*} P<0.05$ (c). 

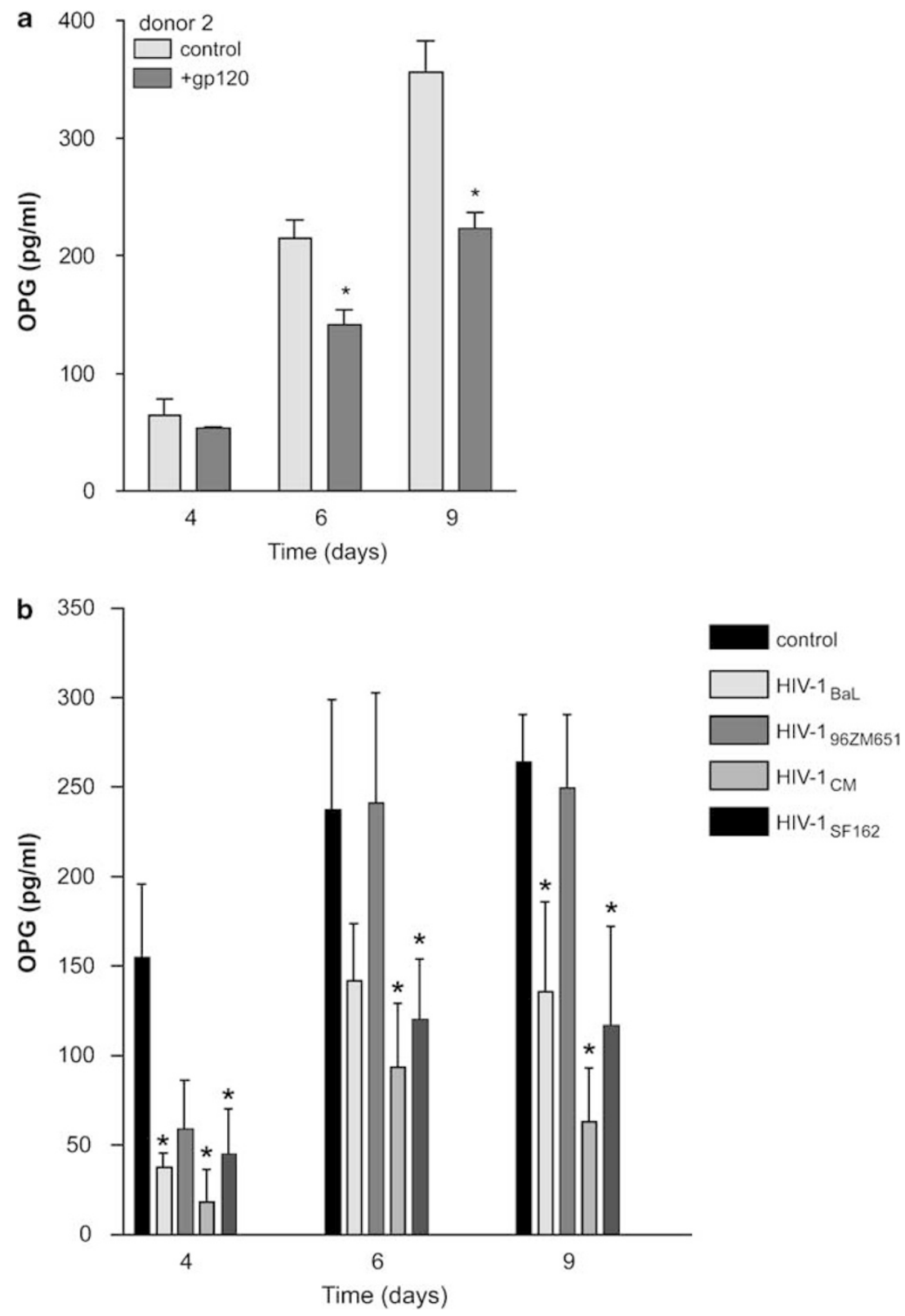

Figure 5 Recombinant full-length HIV-1 gp120 inhibits the production of OPG by normal human blood T lymphocytes. (a) Nonadherent PBML $\left(5 \times 10^{6} / \mathrm{ml}\right)$ were incubated in RPMI $1640+10 \%$ FBS for 9 days in the presence of $500 \mathrm{ng} / \mathrm{ml}$ of one recombinant HIV- 1 gp 120 protein; gp 120 from four different HIV-1 strains were studied. Supernatants were collected at days 4, 6, and 9 to evaluate the concentrations of OPG by EIA. Results are means \pm s.e.m. of data of the effects from each of the four strains on OPG production by nonadherent PBML from healthy donors; results are representative of three different donors. Statistical analysis was performed for each donor by a two-tailed $t$-test (OPG accumulation in the presence of HIV-1 gp120 protein vs matched controls); ${ }^{\star} P<0.05$. (b) CD4-positive T lymphocytes obtained by immunomagnetic isolation from PBML were incubated at $5 \times 10^{6} / \mathrm{ml}$ in $\mathrm{RPMI} 1640+10 \%$ FBS for 9 days in the presence of $500 \mathrm{ng} / \mathrm{ml}$ of the recombinant gp 120 from four HIV- 1 strains. Supernatants were processed as above. Results are means \pm s.e.m. of three different healthy donors. Statistics: paired two-tailed $t$-test, ${ }^{*} P<0.05$.

CD19 + cells) did not generate detectable amounts of OPG in culture (Figure 2a), while peripheral B cells of murine origin are an important source of this decoy receptor. ${ }^{45}$

The production of OPG by T cells was greatly increased by two conditions of stimulation, that is the anti-CD3 $\mathrm{mAb}$ and IL-4 (Figures 1b, 2b, and 3a). The CD3 antigen is associated with the T-cell receptor and its signal transduction. A T-cellspecific immune response in the presence of an anti-CD3 has been shown to induce the production of RANKL and TRAIL. ${ }^{46}$ Thus, the present data on OPG production by T lymphocytes in response to an anti-CD3 $\mathrm{mAb}$ (Figures $1 \mathrm{~b}$ and $2 \mathrm{~b}$ ) suggest a role for OPG to counterbalance the antiCD3-induced production of RANKL or TRAIL. OPG produced by $\mathrm{T}$ cells could have, for instance, a homeostatic role in conditions where TRAIL is implicated in CD4 + killing of antigen-presenting cells, in clonal expansion of $\mathrm{CD} 8+\mathrm{T}$ 

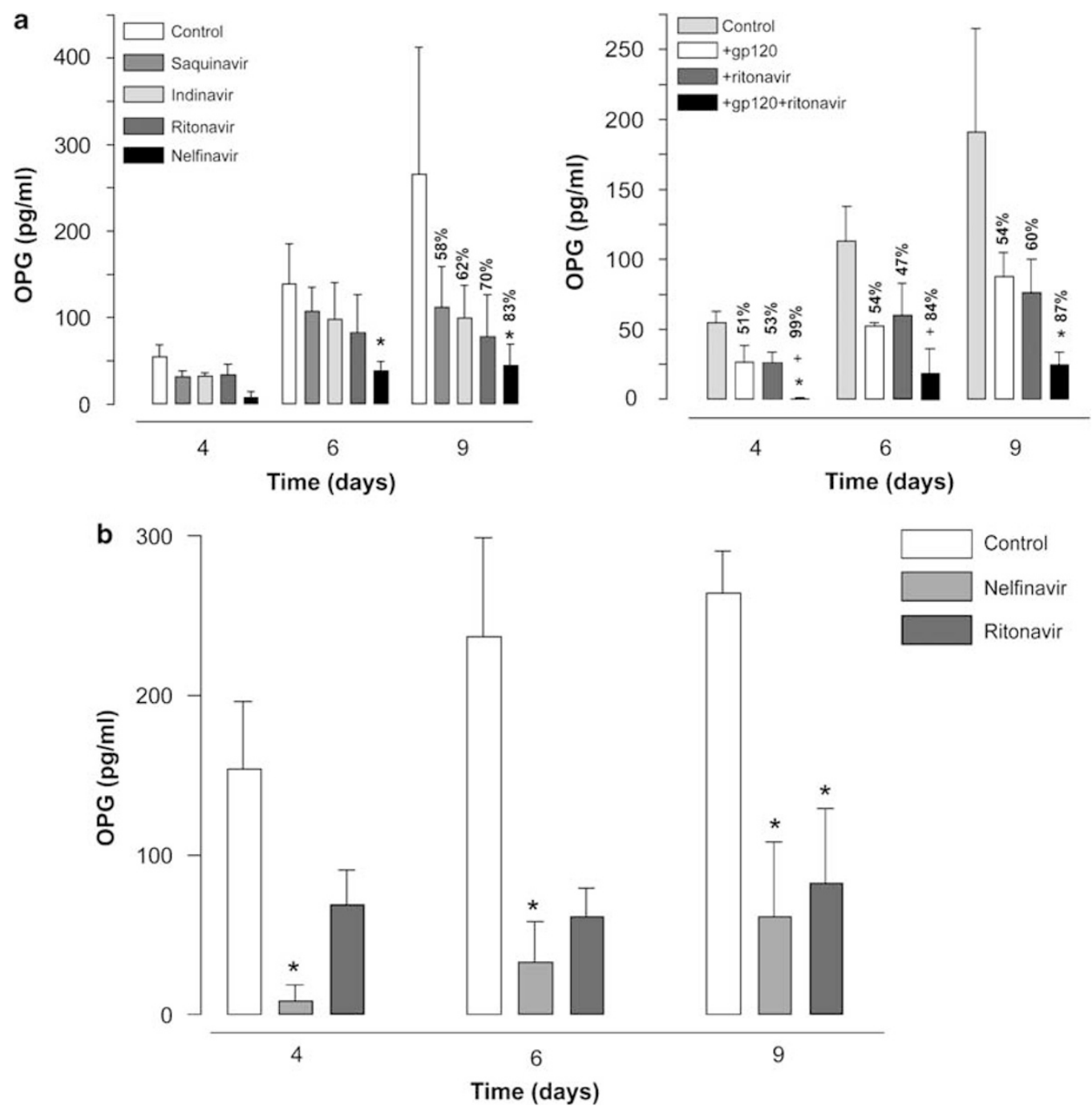

Figure 6 Effects of protease inhibitors (PIs) on the production of OPG by normal human blood T lymphocytes. (a) Nonadherent PBML ( $\left.5 \times 10^{6} / \mathrm{ml}\right)$ were incubated in RPMI $1640+10 \%$ FBS for 9 days in the absence or presence of $10 \mu \mathrm{M}$ saquinavir, indinavir, ritonavir, or nelfinavir (left panel) or were incubated in the presence of $500 \mathrm{ng} / \mathrm{ml}$ of recombinant HIV-1 gp120 protein with or without $10 \mu \mathrm{M}$ ritonavir (right panel). (b) CD4-positive T lymphocytes obtained by immunomagnetic isolation from PBML were incubated at $5 \times 10^{6} / \mathrm{ml}$ in RPMI $1640+10 \%$ FBS for 9 days in the presence of $10 \mu \mathrm{M}$ nelfinavir or ritonavir. Supernatants were successively collected at days 4,6 , and 9 to evaluate the accumulation of OPG by EIA. Results are expressed as means \pm s.e.m. $(n=3)$. Statistics: paired two-tailed $t$-test, ${ }^{\star} P<0.05,{ }^{+} P<0.01$.

memory cells or in apoptosis of primary plasma cells. ${ }^{40,47,48}$ On the other hand, IL-4, a cytokine of the Th2 type, inhibits osteoclast formation and function in vitro and in vivo. ${ }^{49}$ This inhibition involves direct effects of IL-4 on osteoclasts. ${ }^{27,50,51}$ Indirect antiosteoclastogenic effects of IL-4 have been, however, reported that were dependent on $\mathrm{T}$ cells. ${ }^{22}$ Thus, our data on the IL-4 activation of OPG synthesis by T cells (Figure 3a) indicates that indirect inhibitory effects of IL-4 on osteoclastogenesis is not limited to the IL-4 inhibition of RANKL production by $\mathrm{T}$ cells. ${ }^{52}$ The other Th2-type cytokine IL-10 is known to decrease osteoclastogenesis by reducing the differentiation of precursors only, without any effect on mature functional osteoclasts. ${ }^{28}$ However, the strong inhibitory effect of IL-10 on the production of OPG by human blood $\mathrm{T}$ cells (Figure $3 \mathrm{~b}$ and $\mathrm{c}$ ) indicates that, in a context of T-cell-osteoclast interactions, IL-10 could indirectly act on mature osteoclasts by enhancing their functions through a reduced inhibition of RANKL effects. These two Th2 cytokine members have already been shown to differ in their effects. For instance, IL-4, but not IL-10, has antiapoptotic effects on synoviocytes. ${ }^{53}$ The differential mechanisms of the regulation of T-cell synthesis of OPG by IL-4 and IL-10 remain to be elucidated.

The disease caused by the retrovirus HIV-1 initially depends on the $\mathrm{CD} 4+\mathrm{T}$-cell subset. Altered cytokine production is an example of the disordered functions of HIV-infected CD4 $+\mathrm{T}$ cells. ${ }^{23,54}$ Moreover, the envelope glycoprotein gp120 of HIV-1 binds to CD4 determinants on 
normal $\mathrm{T}$ cells and induce immune defects in these lymphocytes. ${ }^{55}$ The present data on the inhibition of T-cell production of OPG by three strains of HIV-1 gp120 proteins (Figure 5) add another candidate molecule to the factors suppressed by these glycoproteins. Surprisingly, the HIV$1_{96 \mathrm{ZM} 651}$ gp120 was the only gp120, among the four tested, that has no effect on the OPG production by $\mathrm{CD} 4+\mathrm{T}$ cells (Figure $5 b$ ), a result also obtained with the whole population of $\mathrm{T}$ cells (Figure 5a). Differential mechanisms of inhibitory vs noninhibitory gp120 proteins on the OPG production by $\mathrm{CD} 4+\mathrm{T}$ cells remain to be elucidated. On the other hand, HIV-1 gp120 proteins have been shown to increase RANKL expression by $\mathrm{T}$ cells. ${ }^{32}$ Certain PIs also increase RANKL by reducing the IFN- $\gamma$-mediated degradation of the RANKL signaling adapter protein TRAF6. ${ }^{32}$ Our findings that certain PIs drastically reduced the production of OPG by $\mathrm{T}$ cells, an effect that was amplified by the presence of HIV-1 gp120 proteins (Figure 6a), indicate that the simultaneous presence of these factors can have major effects on regulatory autacoids of immune response and bone remodeling, such as OPG and RANKL.

Our in vitro data could suggest that patients affected with HIV-1, in particular those receiving PIs, could have abnormal low circulating OPG. We retrospectively measured OPG in plasma from 29 individuals infected with HIV-1. Concentrations of circulating OPG were greatly diminished in HIV-1-infected subjects $(209 \pm 23$ vs $502 \pm 50 \mathrm{pg} / \mathrm{ml}$ for agematched controls). Our results of plasma concentrations of OPG in healthy subjects were in the range of those previously reported using similar anti-OPG antibodies to set up the ELISA. ${ }^{56}$ Despite diverse patient profiles, the diminished CD4 + counts in the HIV individuals studied $(184 \pm 30$ vs $500-1600 / \mathrm{mm}^{3}$ in normal subjects) and the uniformly decreased blood concentrations of OPG were in accordance with the abnormal CD4 characteristics that define the HIVinduced disease. ${ }^{23}$ Our OPG concentrations in plasma from HIV-infected subjects were different from previous data that reported a $52 \%$ increase of serum OPG in their cohort of HIV subjects. ${ }^{57}$ Although OPG concentrations were measured by the same set of anti-OPG antibodies, two major differences between both studies can, however, explain this discrepancy. Firstly, our OPG evaluation was performed on plasma from HIV individuals instead of serum in Ueland et al's report. ${ }^{57}$ It has already been shown that serum concentrations of OPG were significantly higher than those measured in plasma from heparinized blood. ${ }^{58}$ Such differences between serum and plasma measurements could be, at least in part, related to clotting necessary to recover serum. ${ }^{59}$ Secondly, our cohort of HIV subjects was under PIs among HAART used (26/29 patients). Ueland et al's ${ }^{57}$ cohort of HIV individuals received no PIs. In addition to decreasing the spontaneous production of OPG by T cells (Figure 6), PIs were associated with increased incidence of osteoporosis in HIV patients. ${ }^{60,61}$ As a corollary, HIV patients can present an altered circulating OPG concentration. On the other hand, recent studies on HIV-1 pathogenesis point to increased susceptibility of CD4 $+\mathrm{T}$ cells to TRAIL-mediated apoptosis. ${ }^{13,62}$ Concentrations of circulating TRAIL are increased in HIV-1-infected individuals. ${ }^{63}$ Given that OPG is a decoy receptor for TRAIL, our observations of decreased concentrations of circulating OPG in HIV-1-affected subjects could suggest a decreased neutralization of TRAIL and a subsequent enhancement of TRAIL-mediated apoptosis of $\mathrm{CD} 4+\mathrm{T}$ cells. However, it is important to stress that the use of circulating OPG as a clinical marker is controversial. The experimental reasons of these apparent discrepancies have been recently summarized. ${ }^{64}$ Concentrations of circulating OPG evaluated at one time point can be surprisingly increased in bone destructive diseases. This finding has been interpreted as a compensatory response to abnormal osteoclastic activity. ${ }^{64}$ Thus, an appropriate profile of plasma OPG concentrations in HIV-1-affected individuals will require a longitudinal evaluation of multiple plasma samples during several months.

In conclusion, our studies demonstrate the ability of the $\mathrm{CD} 4+$ subset of human blood T lymphocytes to produce a functional OPG protein. The spontaneous and inducible synthesis of OPG by $\mathrm{T}$ cells points to an autoregulatory mechanism to counterbalance the expression of RANKL and TRAIL by these activated cells. Infiltrating $\mathrm{T}$ lymphocytes during diverse pathologies could represent a non-negligible source of OPG with impact on the local immune and bone homeostasis. Moreover, diseases directly related to the CD4 + subset of T cells, such as those associated with HIV-1, could have abnormal tissue responses related to diminished OPG production. This could occur through interactions of infiltrating $\mathrm{T}$ cells with various cell types. The importance of studying the modulation of T-cell-derived OPG is towards a more profound understanding of the manifold activities regulated by OPG in the skeletal and the immune systems. Modulation of OPG production could emerge as an effective therapeutic option for diverse conditions.

\section{ACKNOWLEDGEMENT}

We acknowledge the excellent technical assistance of Mrs Karine Doiron. We also thank Dr Richard Lalonde (Division of Infectious Diseases, Royal Victoria Hospital, McGill University, Montréal, Canada) for collecting plasmas from HIV-1-infected subjects. This work was supported by grants from the Canadian Institutes for Health Research.

1. Emery JG, McDonnell P, Burke MB, et al. Osteoprotegerin is a receptor for the cytotoxic ligand TRAIL. J Biol Chem 1998;273:14363-14367.

2. Yasuda H, Shima N, Nakagawa N, et al. Osteoclast differentiation factor is a ligand for osteoprotegerin/osteoclastogenesis-inhibitory factor and is identical to TRANCE/RANKL. Proc Natl Acad Sci USA 1998;95:3597-3602.

3. Lacey DL, Timms E, Tan HL, et al. Osteoprotegerin ligand is a cytokine that regulates osteoclast differentiation and activation. Cell 1998;93:165-176.

4. Simonet WS, Lacey DL, Dunstan CR, et al. Osteoprotegerin: a novel secreted protein involved in the regulation of bone density. Cell 1997;89:309-319. 
5. Campagnuolo G, Bolon B, Feige U. Kinetics of bone protection by recombinant osteoprotegerin therapy in Lewis rats with adjuvant arthritis. Arthritis Rheum 2002:46:1926-1936.

6. Kong YY, Feige U, Sarosi I, et al. Activated T cells regulate bone loss and joint destruction in adjuvant arthritis through osteoprotegerin ligand. Nature 1999;402:304-309.

7. Wong BR, Josien R, Lee SY, et al. TRANCE (tumor necrosis factor [TNF] related activation-induced cytokine), a new TNF family member predominantly expressed in T cells, is a dendritic cell-specific survival factor. J Exp Med 1997;186:2075-2080.

8. Yasuda H, Shima N, Nakagawa N, et al. Identity of osteoclastogenesis inhibitory factor (OCIF) and osteoprotegerin (OPG): a mechanism by which OPG/OCIF inhibits osteoclastogenesis in vitro. Endocrinology 1998;139:1329-1337.

9. Yun TJ, Tallquist MD, Aicher A, et al. Osteoprotegerin, a crucial regulator of bone metabolism, also regulates $B$ cell development and function. J Immunol 2001;166:1482-1491.

10. Holen I, Croucher PI, Hamdy FC, et al. Osteoprotegerin (OPG) is a survival factor for human prostate cancer cells. Cancer Res 2002;62:1619-1623.

11. Malyankar UM, Scatena $\mathrm{M}$, Suchland $\mathrm{KL}$, et al. Osteoprotegerin is an alpha vbeta 3-induced, NF-kappa B-dependent survival factor for endothelial cells. J Biol Chem 2000;275:20959-20962.

12. Shipman CM, Croucher PI. Osteoprotegerin is a soluble decoy receptor for tumor necrosis factor-related apoptosis-inducing ligand/Apo2 ligand and can function as a paracrine survival factor for human myeloma cells. Cancer Res 2003;63:912-916.

13. Herbeuval JP, Hardy AW, Boasso A, et al. Regulation of TNF-related apoptosis-inducing ligand on primary CD4+ T cells by HIV-1: role of type I IFN-producing plasmacytoid dendritic cells. Proc Natl Acad Sci USA 2005;102:13974-13979.

14. Morel J, Audo R, Hahne $M$, et al. Tumor necrosis factor-related apoptosis-inducing ligand (TRAIL) induces rheumatoid arthritis synovial fibroblast proliferation through mitogen-activated protein kinases and phosphatidylinositol 3-kinase/Akt. J Biol Chem 2005;280:15709-15718.

15. Secchiero P, Gonelli A, Carnevale E, et al. TRAIL promotes the survival and proliferation of primary human vascular endothelial cells by activating the Akt and ERK pathways. Circulation 2003;107: 2250-2256.

16. Theoleyre $S$, Kwan Tat $S$, Vusio $P$, et al. Characterization of osteoprotegerin binding to glycosaminoglycans by surface plasmon resonance: role in the interactions with receptor activator of nuclear factor kappaB ligand (RANKL) and RANK. Biochem Biophys Res Commun 2006;347:460-467.

17. Zauli G, Corallini F, Bossi $F$, et al. Osteoprotegerin increases leukocyte adhesion to endothelial cells both in vitro and in vivo. Blood 2007:110:536-543.

18. Vanderborght $A$, Linsen $L$, Thewissen $M$, et al. Osteoprotegerin and receptor activator of nuclear factor-kappaB ligand mRNA expression in patients with rheumatoid arthritis and healthy controls. J Rheumatol 2004:31:1483-1490.

19. Ziolkowska M, Kurowska M, Radzikowska $A$, et al. High levels of osteoprotegerin and soluble receptor activator of nuclear factor kappa $B$ ligand in serum of rheumatoid arthritis patients and their normalization after anti-tumor necrosis factor alpha treatment. Arthritis Rheum 2002;46:1744-1753.

20. Colucci S, Brunetti G, Rizzi R, et al. T cells support osteoclastogenesis in an in vitro model derived from human multiple myeloma bone disease: the role of the OPG/TRAIL interaction. Blood 2004;104:3722-3730.

21. Horwood NJ, Elliott J, Martin TJ, et al. IL-12 alone and in synergy with IL-18 inhibits osteoclast formation in vitro. J Immunol 2001;166:4915-4921.

22. Mirosavljevic D, Quinn JM, Elliott J, et al. T-cells mediate an inhibitory effect of interleukin-4 on osteoclastogenesis. J Bone Miner Res 2003;18:984-993.

23. Pantaleo G, Graziosi C, Fauci AS. New concepts in the immunopathogenesis of human immunodeficiency virus infection. N Engl J Med 1993;328:327-335.

24. Boyum A. Isolation of mononuclear cells and granulocytes from human blood. Isolation of mononuclear cells by one centrifugation, and of granulocytes by combining centrifugation and sedimentation at $1 \mathrm{~g}$. Scand J Clin Lab Invest Suppl 1968;97:77-89.
25. Grassi J, Roberge CJ, Frobert Y, et al. Determination of IL1 alpha, IL1 beta and IL2 in biological media using specific enzyme immunometric assays. Immunol Rev 1991;119:125-145.

26. Morinaga T, Nakagawa N, Yasuda H, et al. Cloning and characterization of the gene encoding human osteoprotegerin/osteoclastogenesisinhibitory factor. Eur J Biochem 1998;254:685-691.

27. Bizzarri C, Shioi A, Teitelbaum SL, et al. Interleukin-4 inhibits bone resorption and acutely increases cytosolic $\mathrm{Ca} 2+$ in murine osteoclasts. J Biol Chem 1994;269:13817-13824.

28. Owens JM, Gallagher AC, Chambers TJ. IL-10 modulates formation of osteoclasts in murine hemopoietic cultures. J Immunol 1996;157: 936-940.

29. Schneeweis LA, Willard D, Milla ME. Functional dissection of osteoprotegerin and its interaction with receptor activator of NFkappaB ligand. J Biol Chem 2005;280:41155-41164.

30. Capon DJ, Ward RH. The CD4-gp120 interaction and AIDS pathogenesis. Annu Rev Immunol 1991;9:649-678.

31. Su SB, Ueda $\mathrm{H}$, Howard OM, et al. Inhibition of the expression and function of chemokine receptors on human CD4+ leukocytes by HIV-1 envelope protein gp120. Chem Immunol 1999;72: 141-160.

32. Fakruddin JM, Laurence J. HIV envelope gp120-mediated regulation of osteoclastogenesis via receptor activator of nuclear factor kappa $B$ ligand (RANKL) secretion and its modulation by certain HIV protease inhibitors through interferon-gamma/RANKL cross-talk. J Biol Chem 2003; $278: 48251-48258$.

33. Giuliani N, Colla $S$, Sala $R$, et al. Human myeloma cells stimulate the receptor activator of nuclear factor-kappa $B$ ligand (RANKL) in T lymphocytes: a potential role in multiple myeloma bone disease. Blood 2002;100:4615-4621.

34. Ashcroft AJ, Cruickshank SM, Croucher PI, et al. Colonic dendritic cells, intestinal inflammation, and T cell-mediated bone destruction are modulated by recombinant osteoprotegerin. Immunity 2003;19: 849-861.

35. Neville-Webbe HL, Cross NA, Eaton $\mathrm{CL}$, et al. Osteoprotegerin (OPG) produced by bone marrow stromal cells protects breast cancer cells from TRAIL-induced apoptosis. Breast Cancer Res Treat 2004;86: 269-279.

36. Kanamaru $\mathrm{F}$, Iwai $\mathrm{H}$, Ikeda $\mathrm{T}$, et al. Expression of membrane-bound and soluble receptor activator of NF-kappaB ligand (RANKL) in human T cells. Immunol Lett 2004;94:239-246.

37. Mirandola P, Ponti C, Gobbi G, et al. Activated human NK and CD8+ T cells express both TNF-related apoptosis-inducing ligand (TRAIL) and TRAIL receptors but are resistant to TRAIL-mediated cytotoxicity. Blood 2004;104:2418-2424.

38. Tsai HF, Lai JJ, Chou AH, et al. Induction of costimulation of human CD4 T cells by tumor necrosis factor-related apoptosis-inducing ligand: possible role in T cell activation in systemic lupus erythematosus. Arthritis Rheum 2004;50:629-639.

39. Weitzmann MN, Cenci $S$, Rifas $L$, et al. T cell activation induces human osteoclast formation via receptor activator of nuclear factor kappaB ligand-dependent and -independent mechanisms. J Bone Miner Res 2001;16:328-337.

40. Janssen EM, Droin NM, Lemmens EE, et al. CD4+ T-cell help controls CD8+ T-cell memory via TRAIL-mediated activation-induced cell death. Nature 2005;434:88-93.

41. Fujita T, Matsui T, Nakao Y, et al. Cytokines and osteoporosis. Ann NY Acad Sci 1990;587:371-375.

42. Takayanagi $\mathrm{H}$, Ogasawara $\mathrm{K}$, Hida $\mathrm{S}$, et al. T-cell-mediated regulation of osteoclastogenesis by signalling cross-talk between RANKL and IFNgamma. Nature 2000;408:600-605.

43. Shinoda K, Sugiyama E, Taki $H$, et al. Resting $T$ cells negatively regulate osteoclast generation from peripheral blood monocytes. Bone 2003;33:711-720.

44. Wyzga N, Varghese S, Wikel S, et al. Effects of activated T cells on osteoclastogenesis depend on how they are activated. Bone 2004;35:614-620.

45. Li $Y$, Toraldo $G$, Li A, et al. B cells and $T$ cells are critical for the preservation of bone homeostasis and attainment of peak bone mass in vivo. Blood 2007;109:3839-3848.

46. Wang $R$, Zhang $L$, Zhang $X$, et al. Regulation of activation-induced receptor activator of NF-kappaB ligand (RANKL) expression in T cells. Eur J Immunol 2002;32:1090-1098. 
47. Kaplan MJ, Ray D, Mo RR, et al. TRAIL (Apo2 ligand) and TWEAK (Apo3 ligand) mediate CD4+ $T$ cell killing of antigen-presenting macrophages. J Immunol 2000;164:2897-2904.

48. Ursini-Siegel J, Zhang W, Altmeyer A, et al. TRAIL/Apo-2 ligand induces primary plasma cell apoptosis. J Immunol 2002;169:5505-5513.

49. Lubberts $E$, Joosten LA, Chabaud $M$, et al. IL-4 gene therapy for collagen arthritis suppresses synovial IL-17 and osteoprotegerin ligand and prevents bone erosion. J Clin Invest 2000;105:1697-1710.

50. Abu-Amer Y. IL-4 abrogates osteoclastogenesis through STAT6dependent inhibition of NF-kappaB. J Clin Invest 2001;107:1375-1385.

51. Bendixen AC, Shevde NK, Dienger KM, et al. IL-4 inhibits osteoclast formation through a direct action on osteoclast precursors via peroxisome proliferator-activated receptor gamma 1. Proc Natl Acad Sci USA 2001;98:2443-2448.

52. Josien $\mathrm{R}$, Wong BR, Li HL, et al. TRANCE, a TNF family member, is differentially expressed on $\mathrm{T}$ cell subsets and induces cytokine production in dendritic cells. J Immunol 1999;162:2562-2568.

53. Relic B, Guicheux J, Mezin F, et al. II-4 and IL-13, but not IL-10, protect human synoviocytes from apoptosis. J Immunol 2001;166:2775-2782.

54. Meyaard L, Otto SA, Keet IP, et al. Changes in cytokine secretion patterns of CD4+ T-cell clones in human immunodeficiency virus infection. Blood 1994;84:4262-4268.

55. Oyaizu N, Chirmule N, Kalyanaraman VS, et al. Human immunodeficiency virus type 1 envelope glycoprotein gp120 produces immune defects in CD4+ T lymphocytes by inhibiting interleukin 2 mRNA. Proc Natl Acad Sci USA 1990;87:2379-2383.

56. Trofimov S, Pantsulaia I, Kobyliansky E, et al. Circulating levels of receptor activator of nuclear factor-kappaB ligand/osteoprotegerin/ macrophage-colony stimulating factor in a presumably healthy human population. Eur J Endocrinol 2004;150:305-311.

57. Ueland T, Bollerslev J, Godang K, et al. Increased serum osteoprotegerin in disorders characterized by persistent immune activation or glucocorticoid excess - possible role in bone homeostasis. Eur J Endocrinol 2001;145:685-690.

58. Chan BY, Buckley KA, Durham BH, et al. Effect of anticoagulants and storage temperature on the stability of receptor activator for nuclear factor-kappa B ligand and osteoprotegerin in plasma and serum. Clin Chem 2003;49:2083-2085.

59. Webb NJ, Bottomley MJ, Watson CJ, et al. Vascular endothelial growth factor (VEGF) is released from platelets during blood clotting: implications for measurement of circulating VEGF levels in clinical disease. Clin Sci (Lond) 1998;94:395-404.

60. Moore AL, Vashisht A, Sabin CA, et al. Reduced bone mineral density in HIV-positive individuals. Aids 2001;15:1731-1733.

61. Tebas P, Powderly WG, Claxton S, et al. Accelerated bone mineral loss in HIV-infected patients receiving potent antiretroviral therapy. Aids 2000;14:F63-F67.

62. Lum JJ, Schnepple DJ, Badley AD. Acquired T-cell sensitivity to TRAIL mediated killing during HIV infection is regulated by CXCR4-gp120 interactions. Aids 2005;19:1125-1133.

63. Herbeuval JP, Boasso A, Grivel JC, et al. TNF-related apoptosis-inducing ligand (TRAIL) in HIV-1-infected patients and its in vitro production by antigen-presenting cells. Blood 2005;105:2458-2464.

64. Rogers A, Eastell R. Circulating osteoprotegerin and receptor activator for nuclear factor kappaB ligand: clinical utility in metabolic bone disease assessment. J Clin Endocrinol Metab 2005;90:6323-6331. 